\title{
ИСТОРИЯ
}

\section{Чин сэтгэлт шинэ торгууд аймагийн билигт джун ван Шеаренгийн тухай хэдэн асуудал (= Предводитель «новых» торгутов Шеаренг-тайша)}

\author{
Уэсень Гаова 1 \\ ${ }^{1}$ Синьцзянский государственный университет (д. 14, ул. Шенгли, 830046 Урумчи, \\ Синьцзян-Уйгурский автономный район, КНР) \\ преподаватель \\ E-mail: mengke64@163.com
}

(C) КалмНЦ РАН, 2020

(C) Ужень Гаова, 2020

\begin{abstract}
Аннотация. Имя тайши Шеаренга хорошо известно по историческим документам, при этом достоверная биография его неизвестна. В различных источниках встречаются порой противоречивые сведения о его происхождении и количестве его подданных. В силу обстоятельств, сложившихся вследствие падения Джунгарского ханства в 1758 г., тайша Шеаренг со своими подданными оказался в калмыцких кочевьях на p. Волге. Согласно выводам некоторых исследователей, он был одним из инициаторов откочевки калмыков в 1771 г. с берегов р. Волги. После перекочевки в пределы прежнего отечества тайша Шеаренг был возведен маньчжурским императором в звание цзюньвана, а местом кочевки его подданных была определена территория современного Ховдского аймака Монголии. В данной статье приводятся данные о родословной тайши Шеаренга и количестве его подданных по известным историческим летописям и архивным источникам.

Ключевые слова: Шеаренг-тайша, «новые» торгуты, родословная, количество подданных

Благодарность. Материалы статьи апробированы на Международной научной онлайн-конференции «Монголоведение в начале XXI в.: современное состояние и перспективы развития - ІІ», проведенной при финансовой поддержке РФФИ (проект № 20-09-22004) и частичной поддержке гранта Правительства РФ (№ 075-15-2019-1879). Для цитирования: Ужень Гаова. Чин сэтгэлт шинэ торгууд аймагийн билигт джуан ван Шеаренгийн тухай хэдэн асуудал (= Предводитель «новых» торгутов Шеаренг-тайша) // Монголоведение. 2020. Т. 12. № 4. С. 692-700. (На монг.). DOI: 10.22162/2500-15232020-4-692-700
\end{abstract}


UDC 94 (517)

DOI: $10.22162 / 2500-1523-2020-4-692-700$

\title{
Warlord of the "new" torguts of Shearing Taisha
}

\author{
Wuren Gaova ${ }^{1}$ \\ ${ }^{1}$ Xinjiang state University (14, Shengli Road, Urumqi, Xinjiang 830046, China) \\ Lecturer \\ E-mail: mengke64@163.com
}

CKalmSC RAS, 2020

(C) Wuren Gaova, 2020

\begin{abstract}
The name of Taishi Sheareng is well known from historical documents. At the same time, his pre-war biography is unknown. Various sources sometimes contain contradicting information about his origin and the quanitity of his vassals. Due to the circumstances resulting from the fall of the Dzhungar Khanate in 1758, Taisha Sheareng with his vassals ended up in Kalmyk nomad camps on Volga. According to the conclusions of some ivestigations, he was one of the initiators of the migration of the Kalmyks in 1771 from the banks of Volga. After migrating to the borders of the former homeland, Taisha Sheareng was elevated to the rank of Junwang by the Manchu emperor, and the territory of the modern Khovd aimag of Mongolia was defined as the place of residence of his vassals. This publication provides data on the pedigree of Taishi Sheareng and the number of his vassals according to well-known historical chronicles and archival sources.
\end{abstract}

Keywords: Sheareng taisha, "new" Torguts, pedigree, number of subjects

Acknowledgments. The article was presented at the international scientific online conference "Mongolian Studies at the beginning of the 21st century: Current State and Development Prospects - II”, held with the financial support of RFBR (project № 20-09-22004) and partial support of the Russian Government Grant (№ 075-15-2019-1879).

For citation: Wuren Gaova. Warlord of the "new" torguts of Shearing Taisha. Mongolian Studies (Elista). 2020. Vol. 12. No. 4. Pp. 692-700. (In Mong.). DOI: 10.22162/2500-15232020-4-692-700 


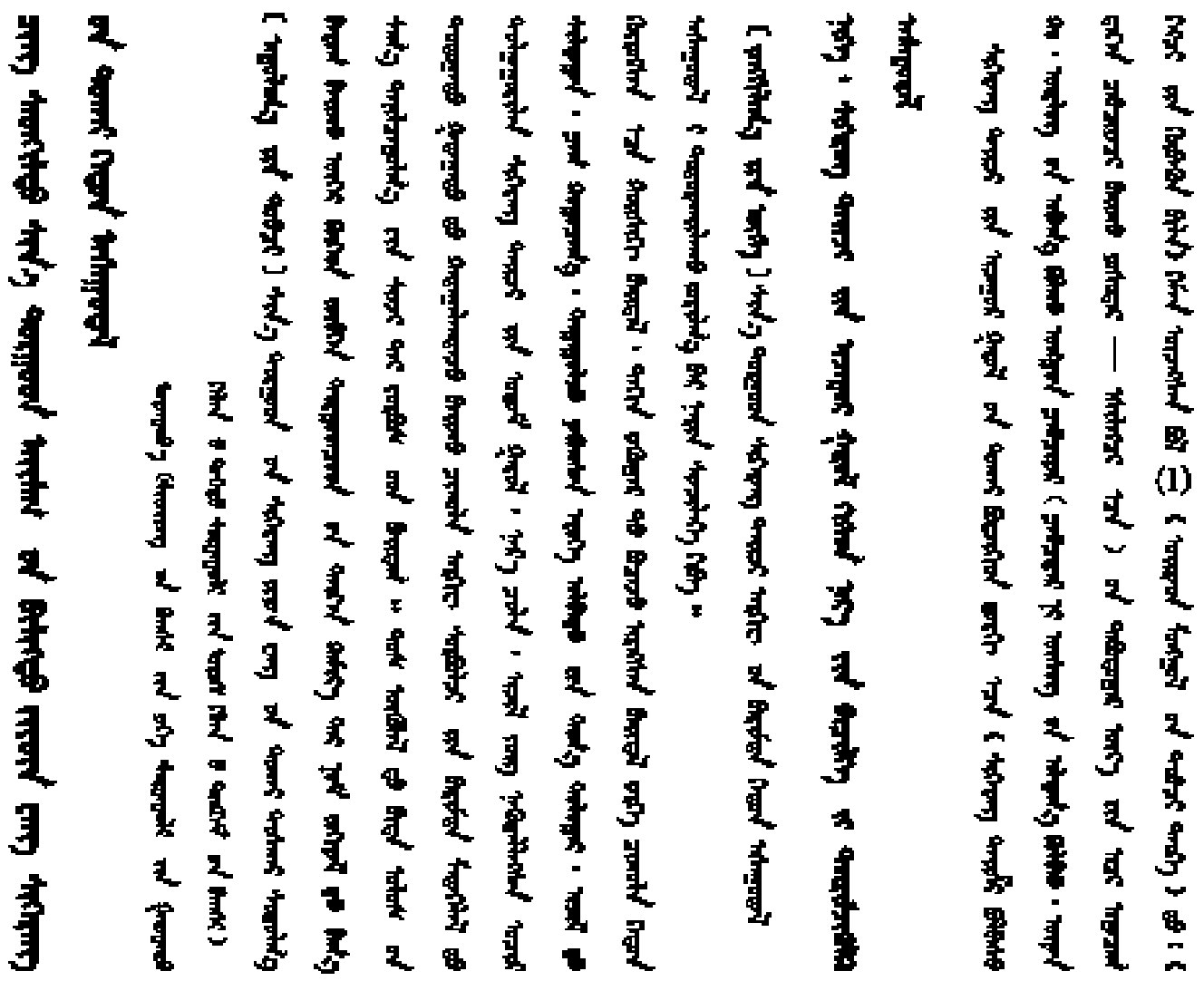

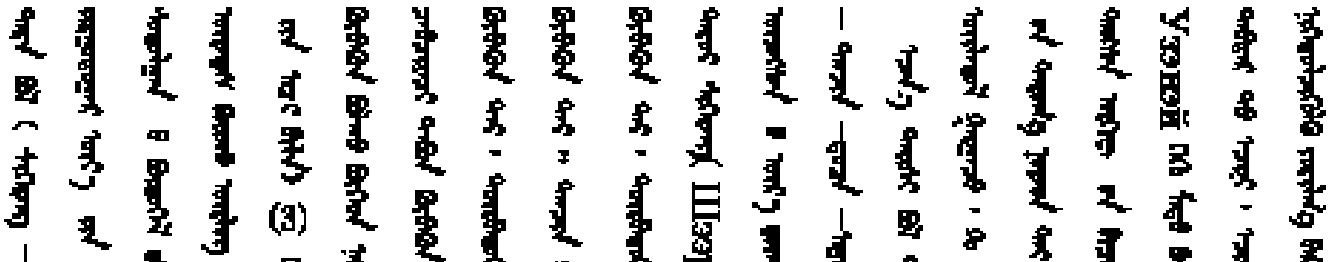

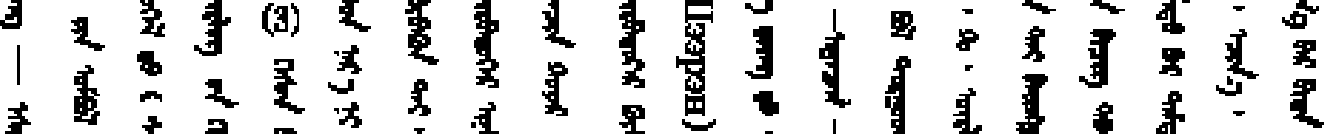

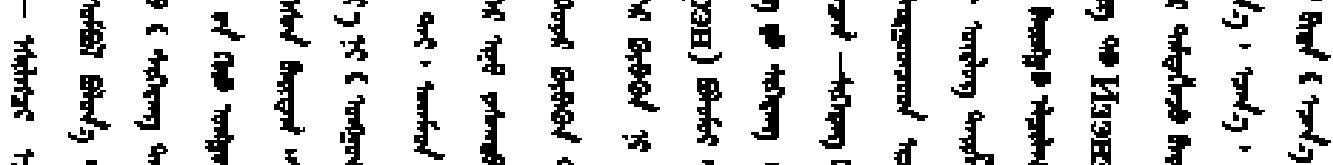

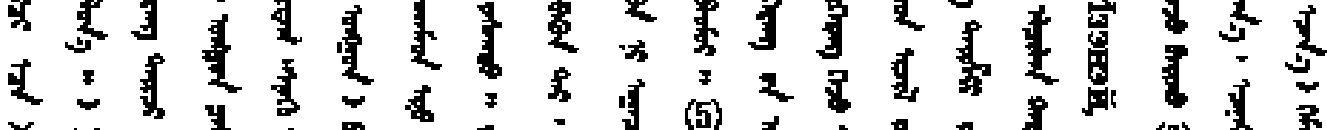
(2)

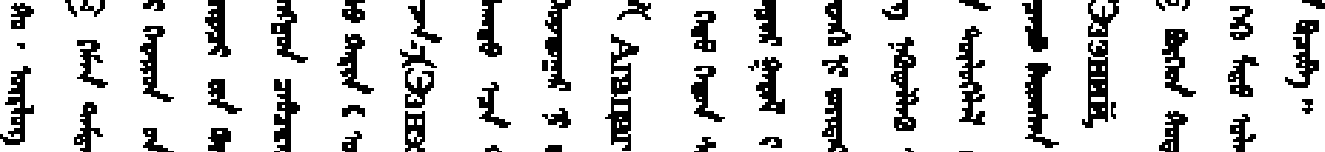

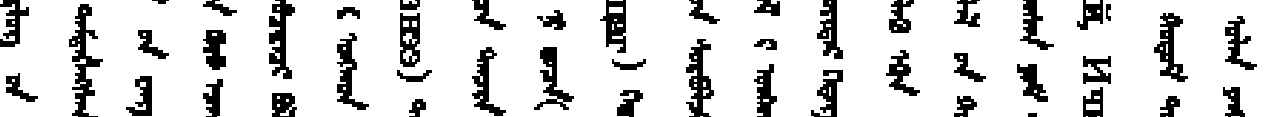

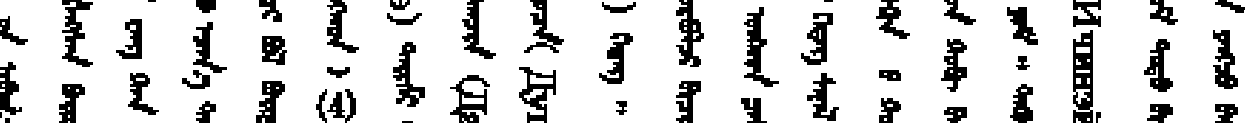
I I to

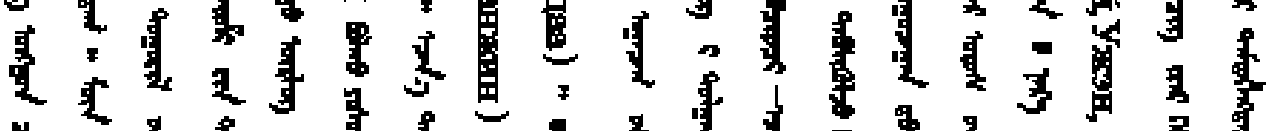

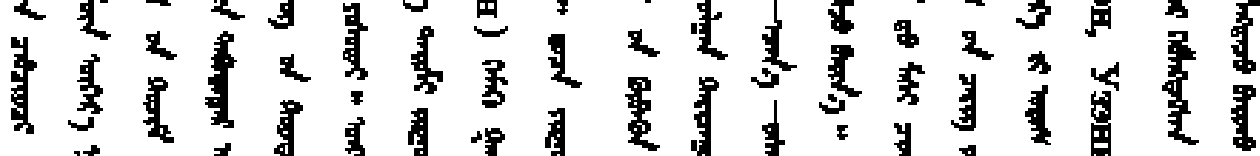

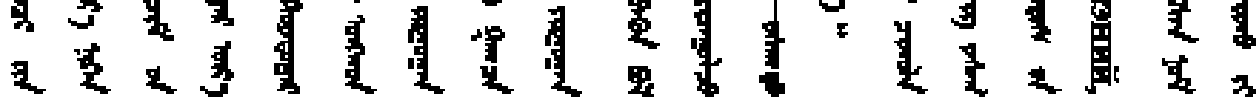




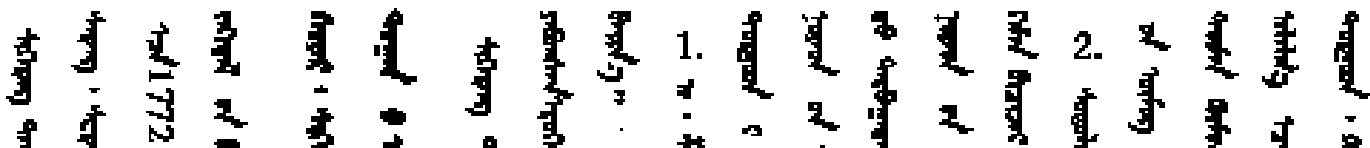
1)

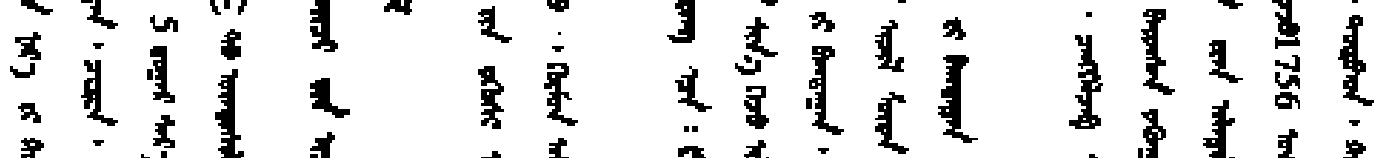

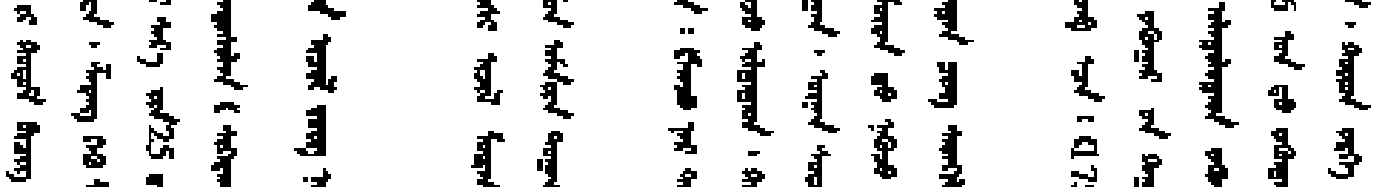

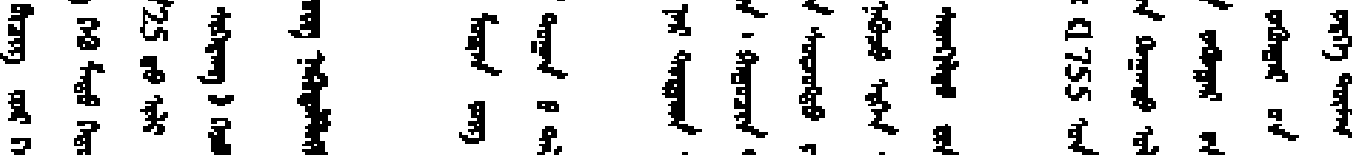

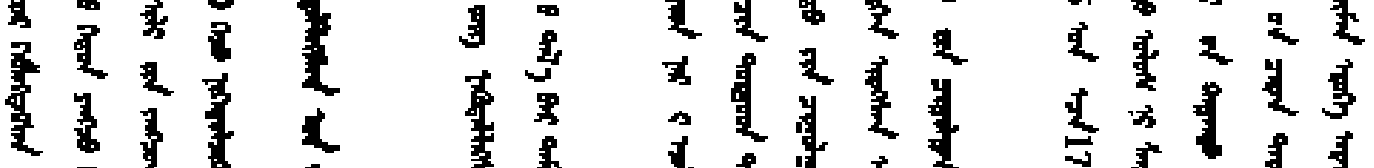

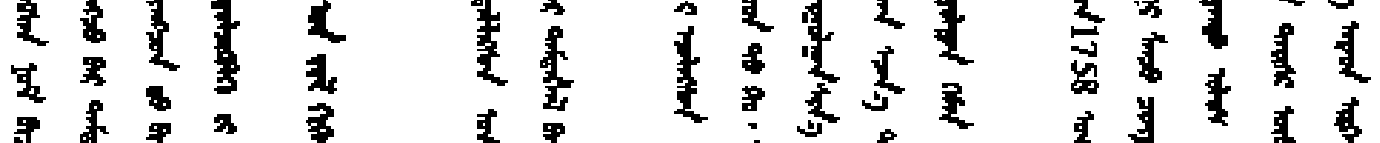

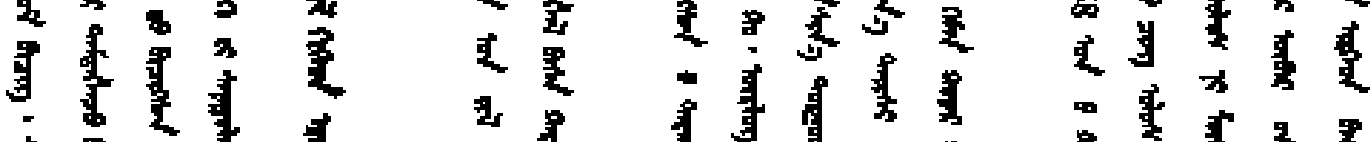

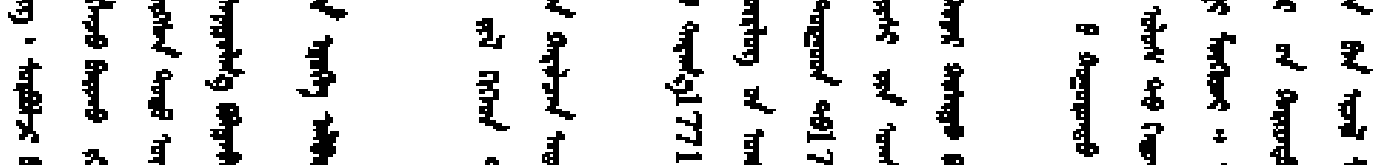

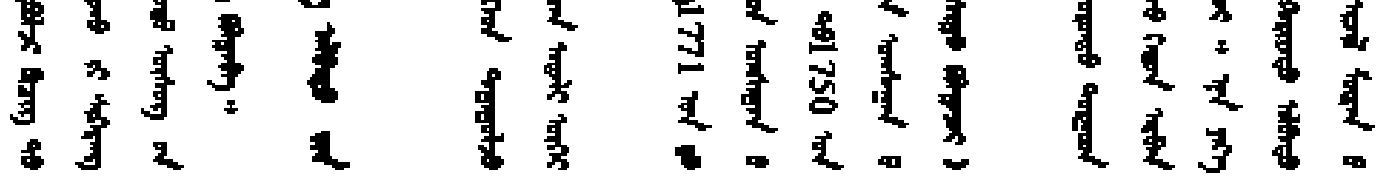
1 3. 1 1

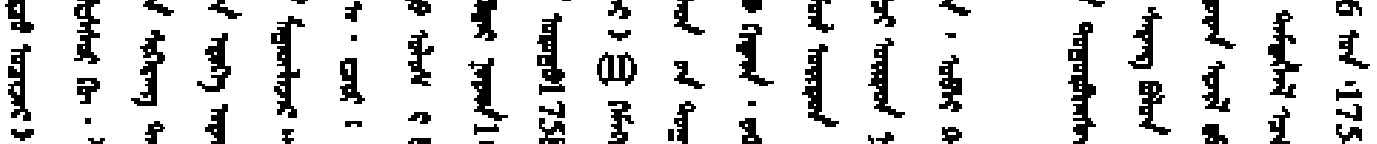

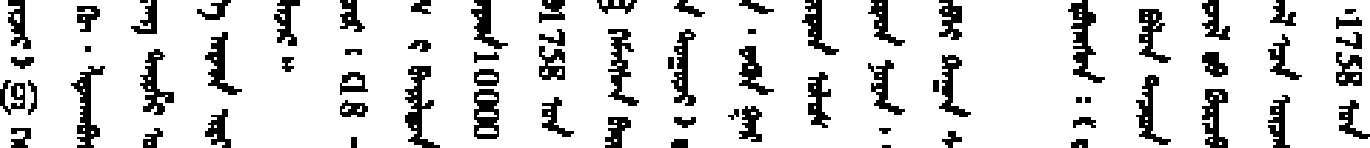

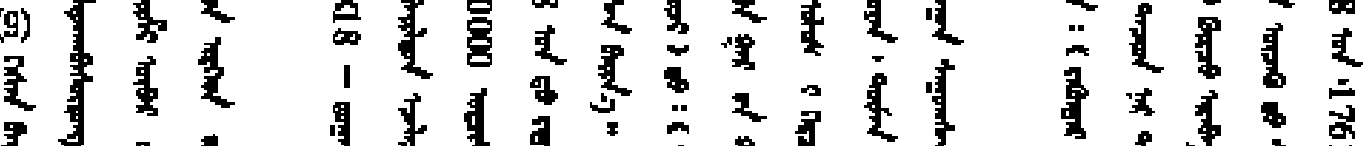

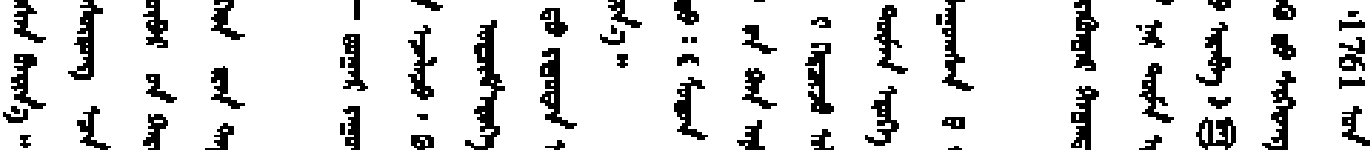

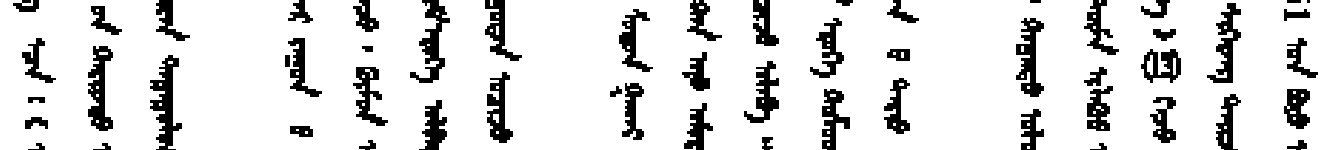

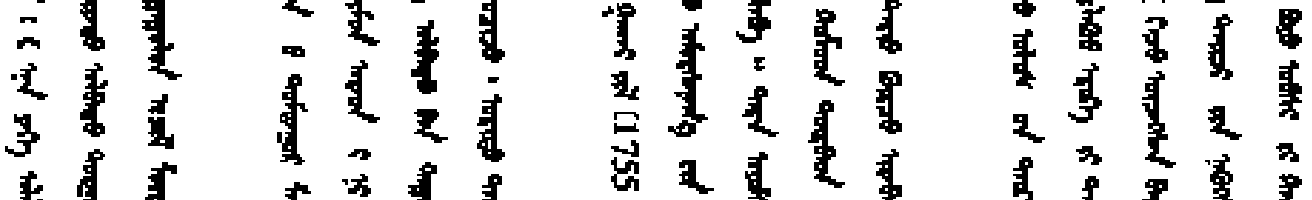

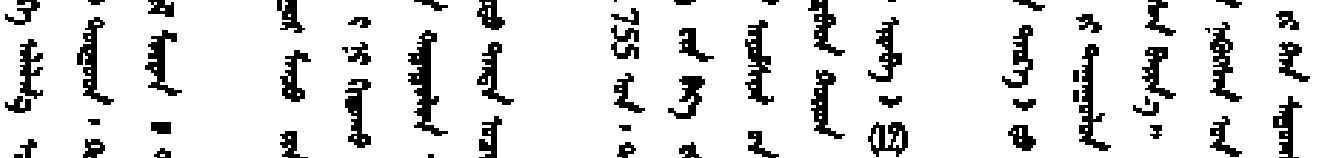

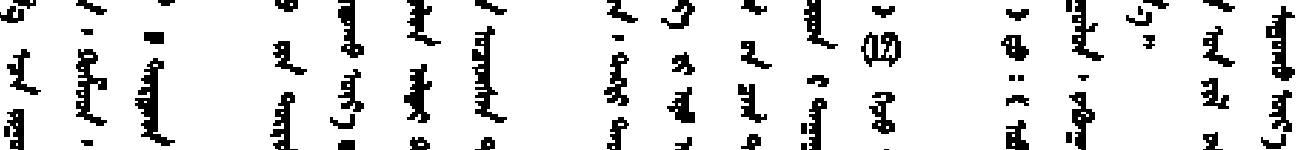

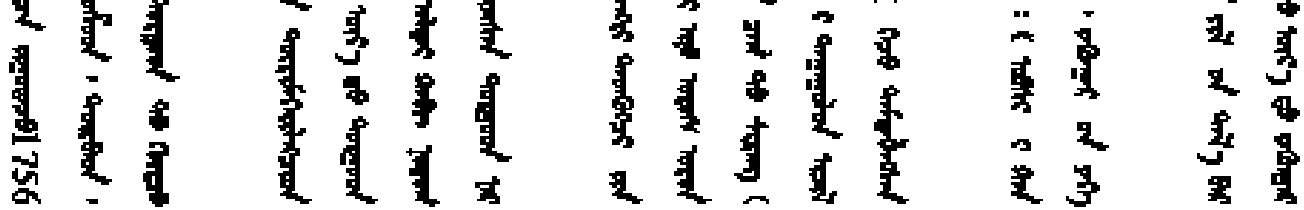




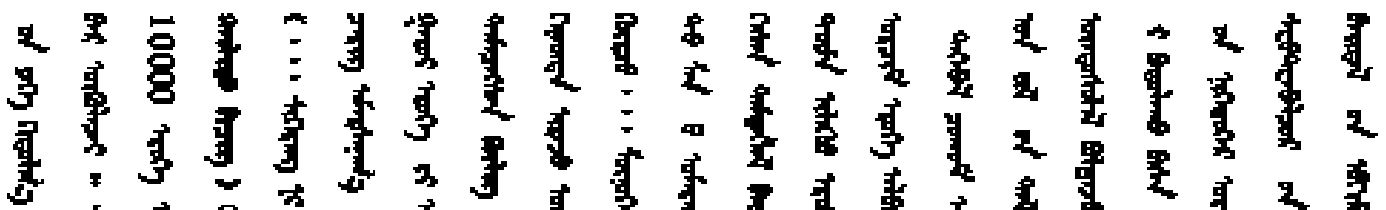

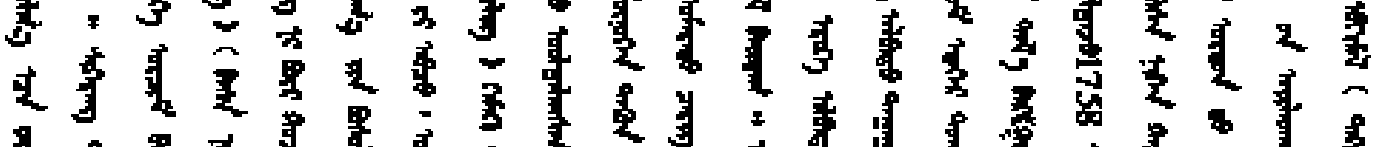

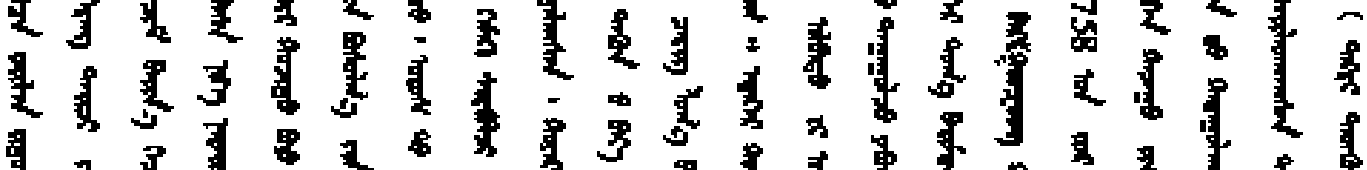

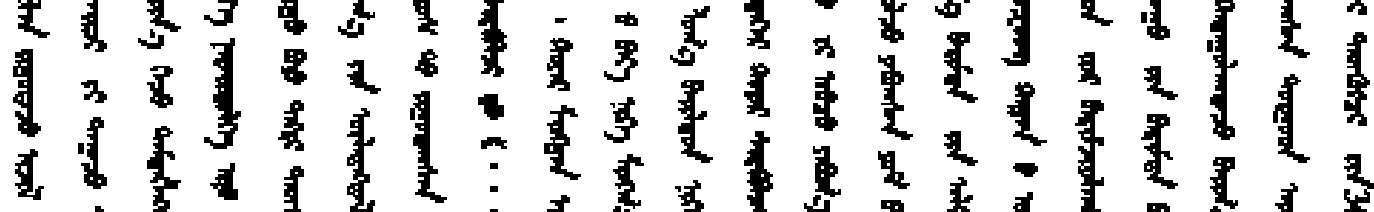

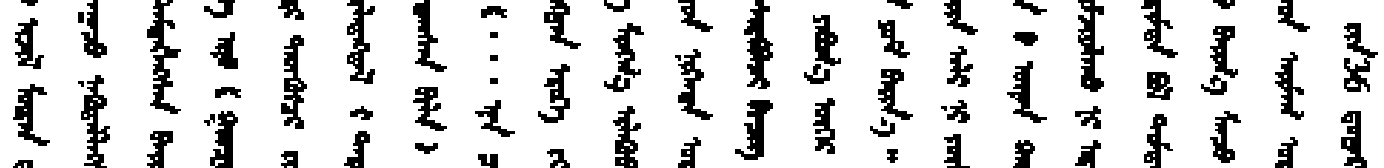

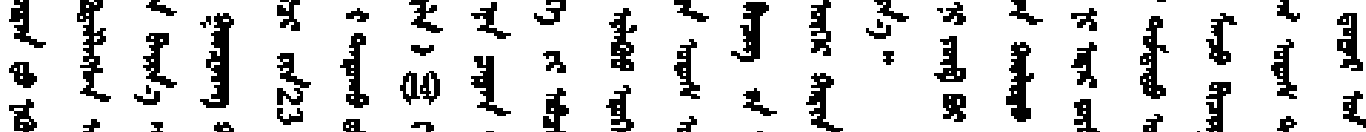

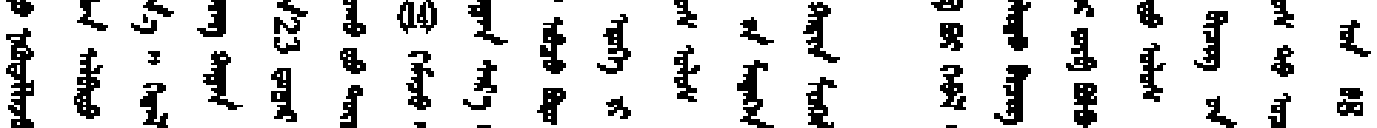

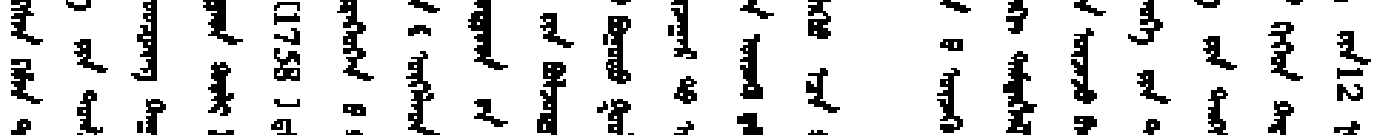

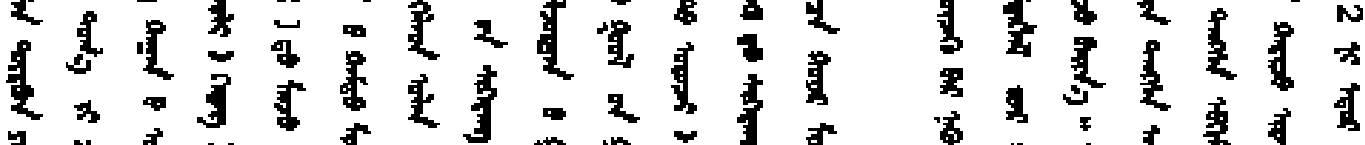
星

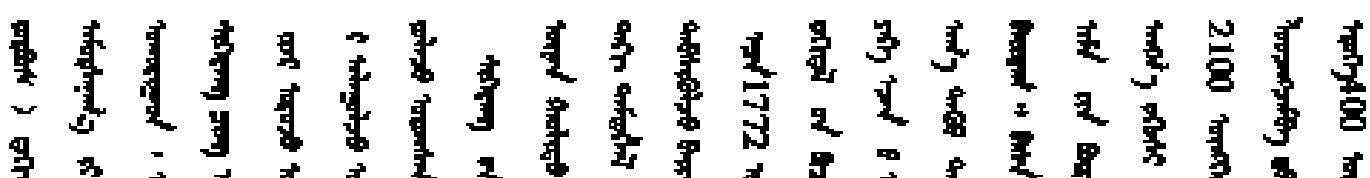

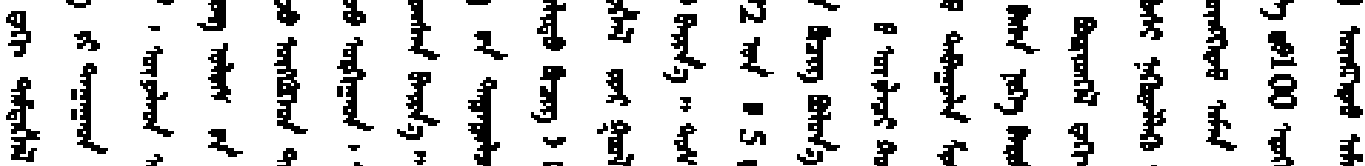

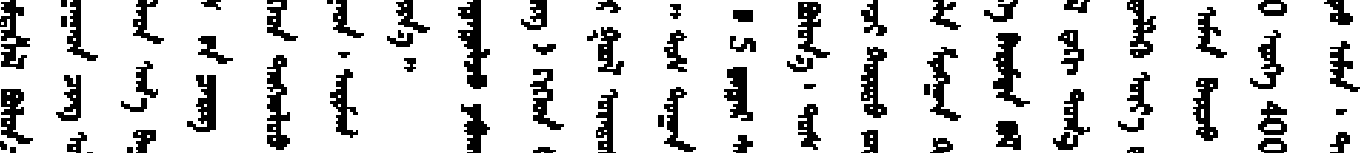

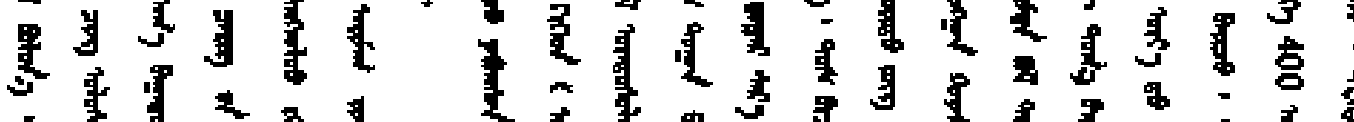
(1)

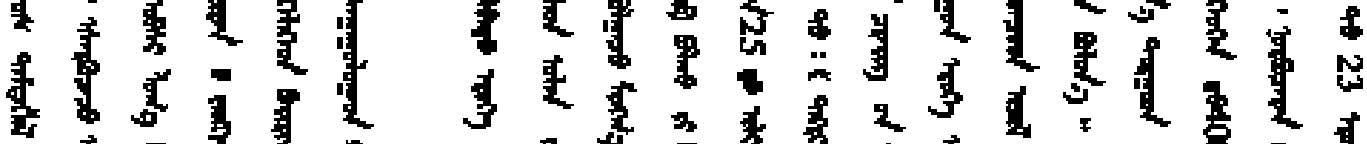

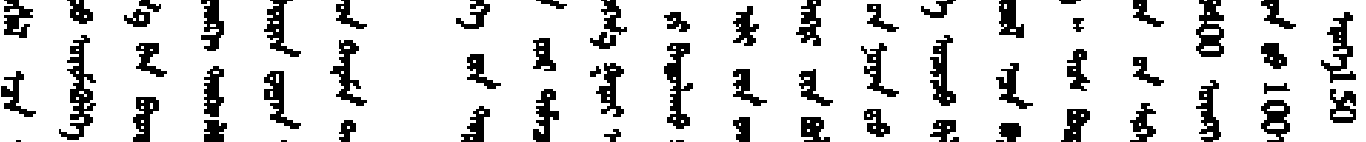

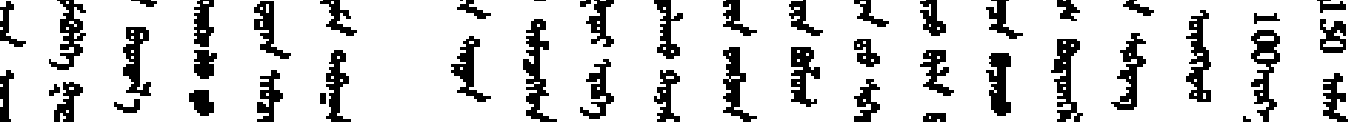
1

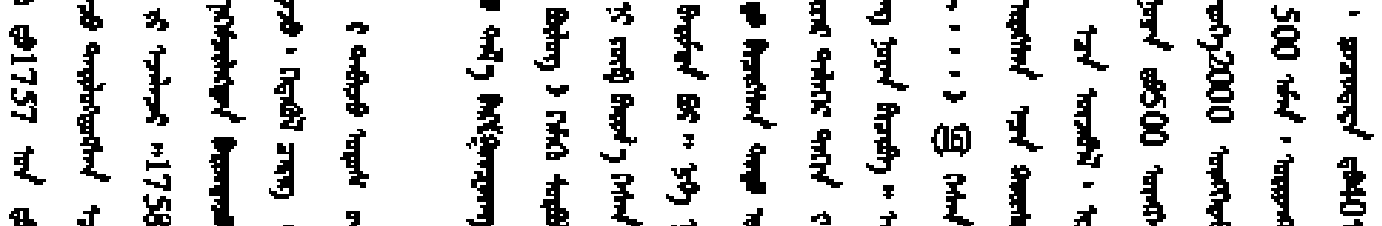

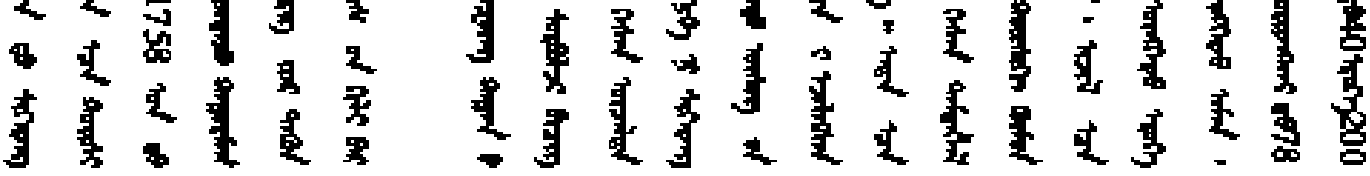




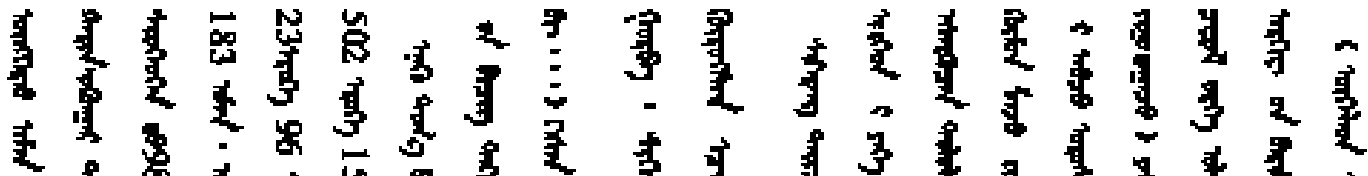

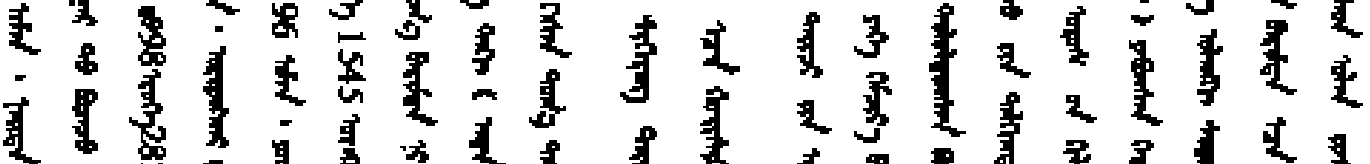

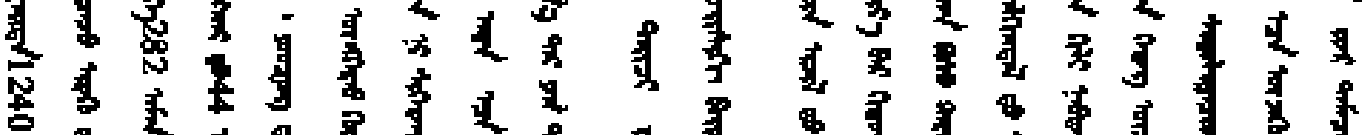

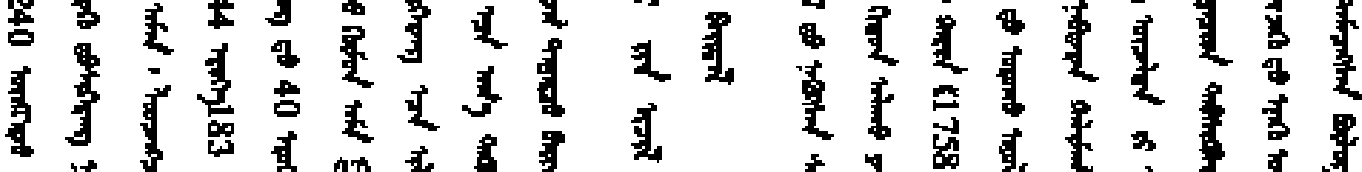

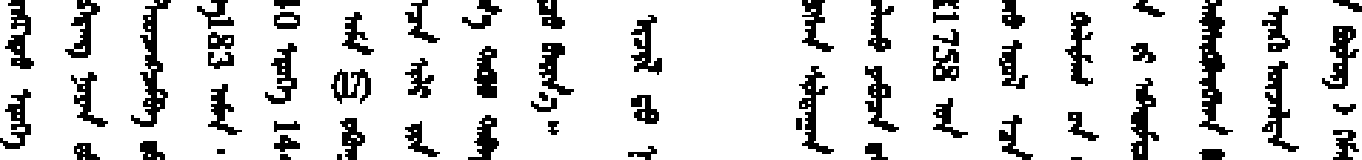

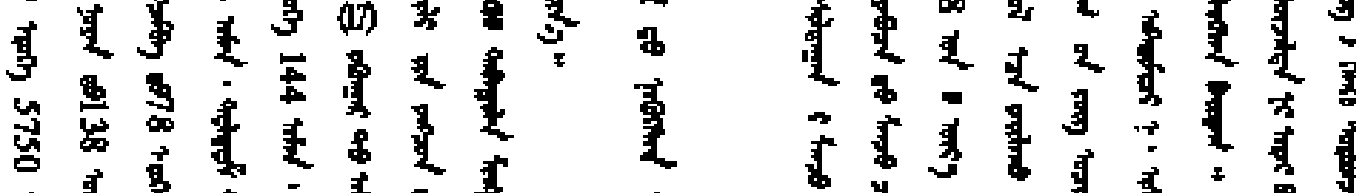

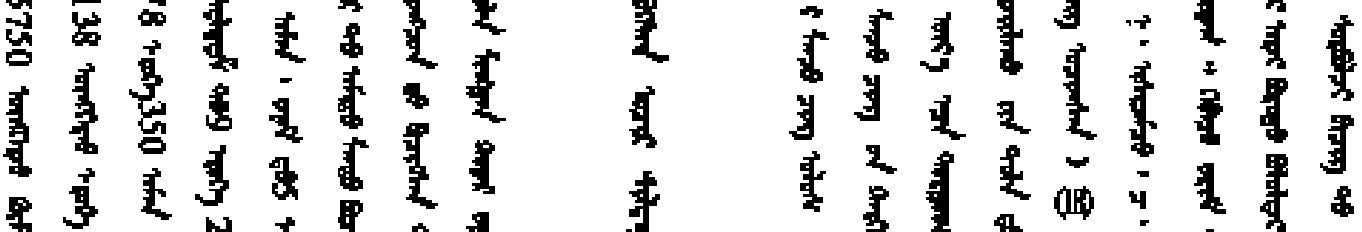

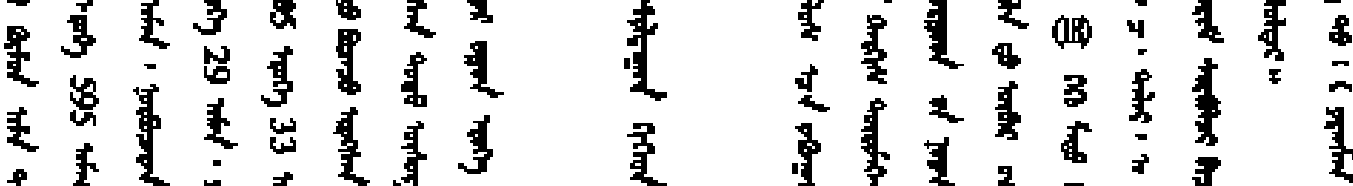

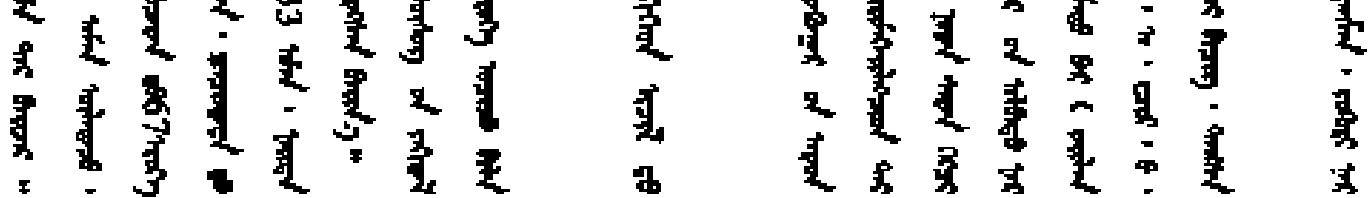

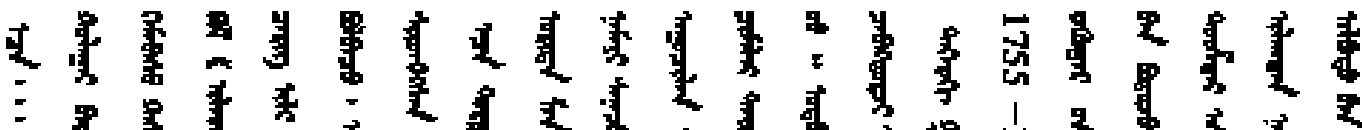
s

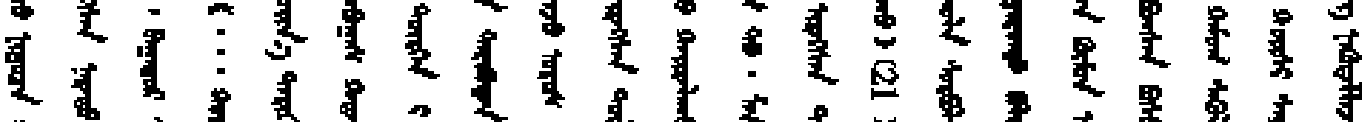

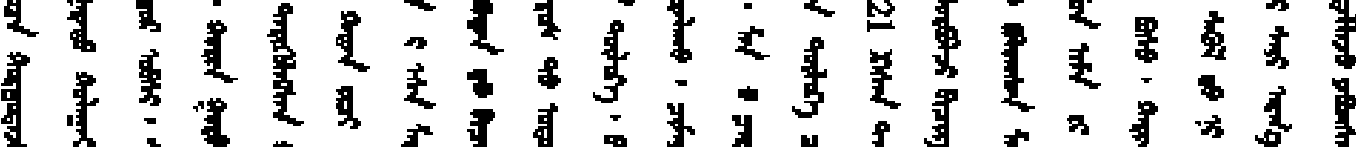

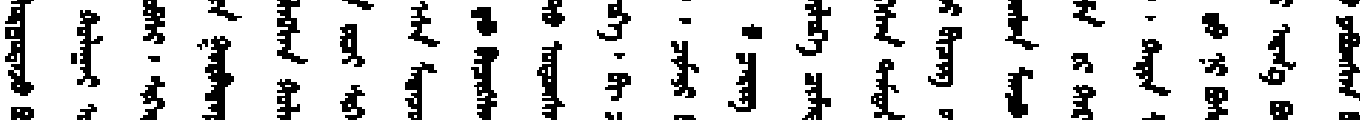

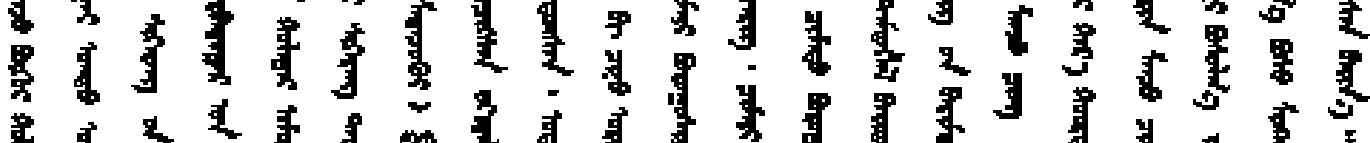

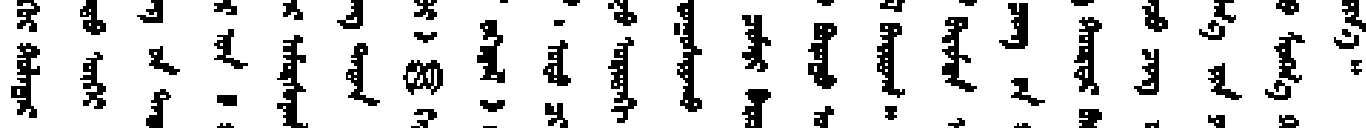

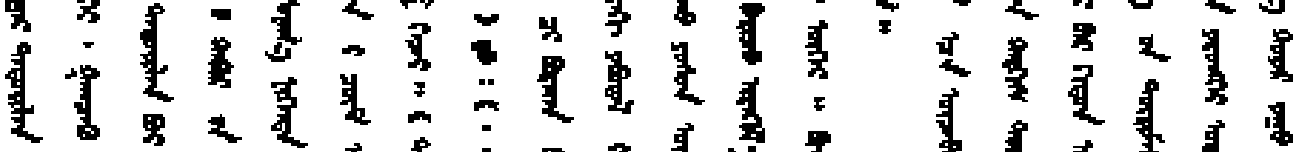

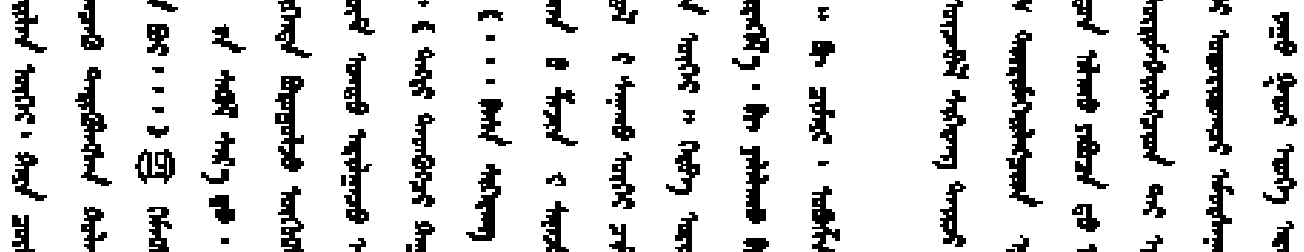

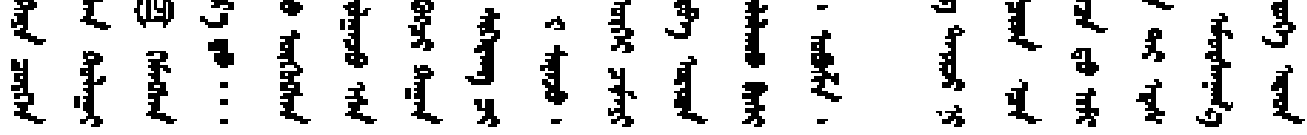




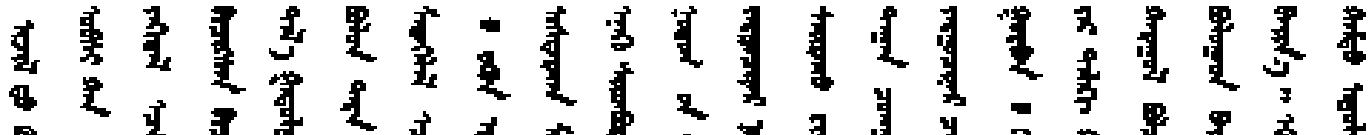

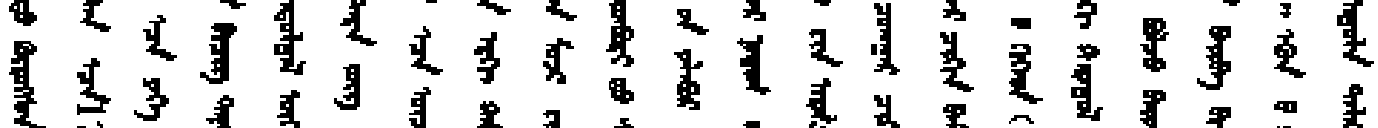

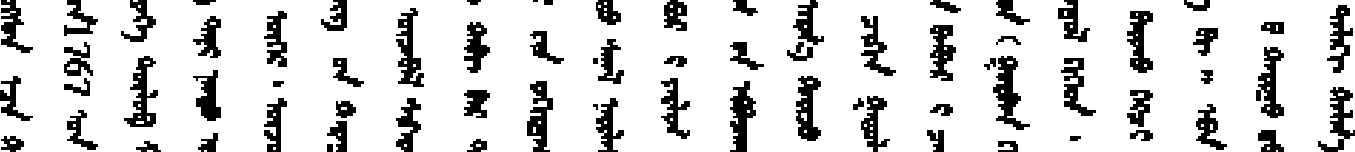

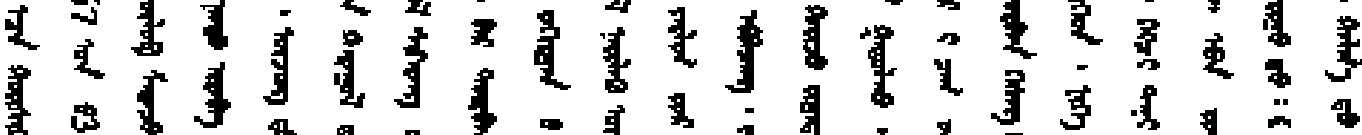
(1)

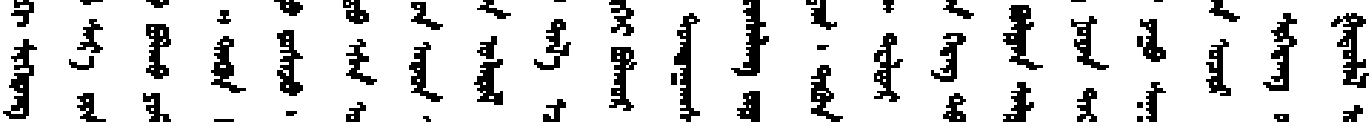

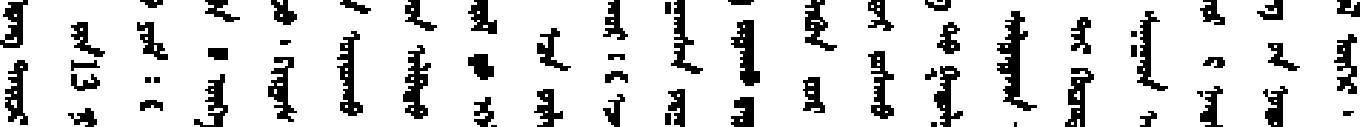

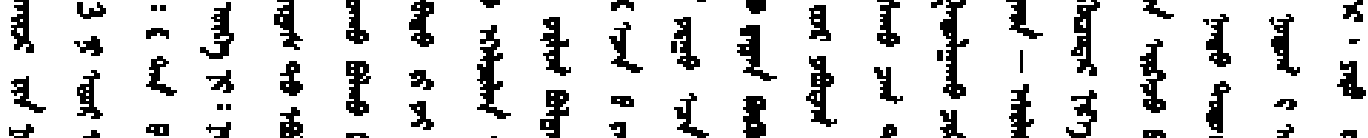

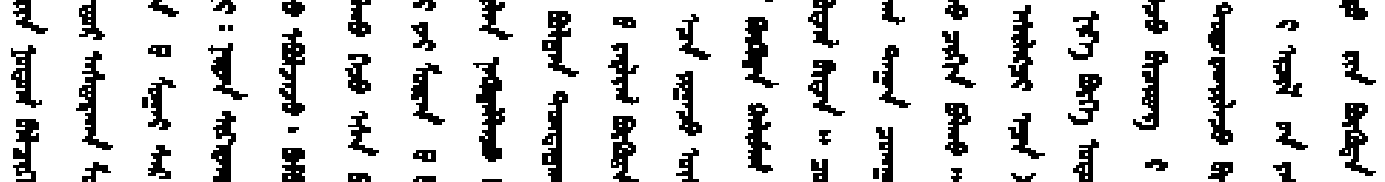

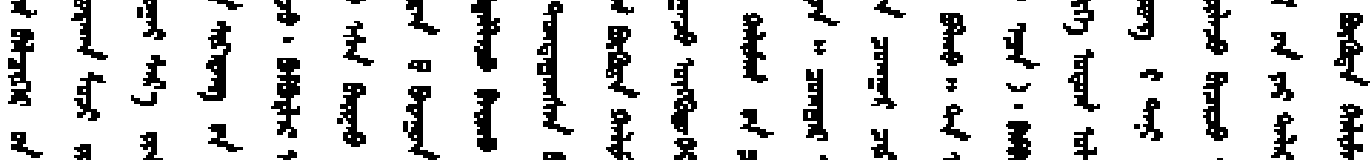

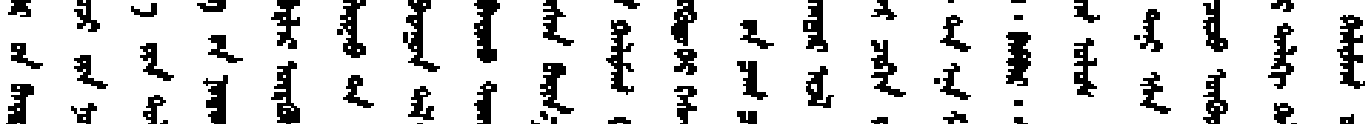

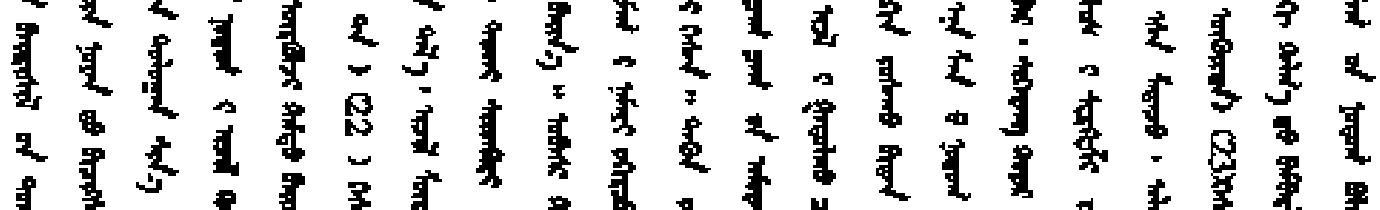

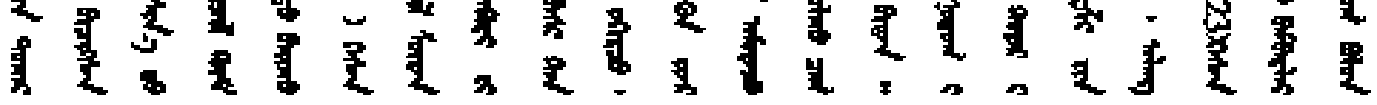

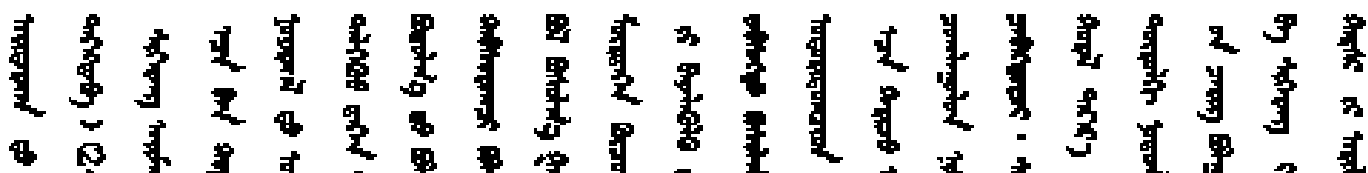
-

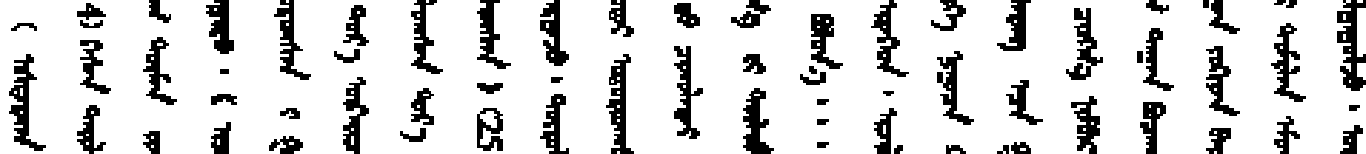
1 告

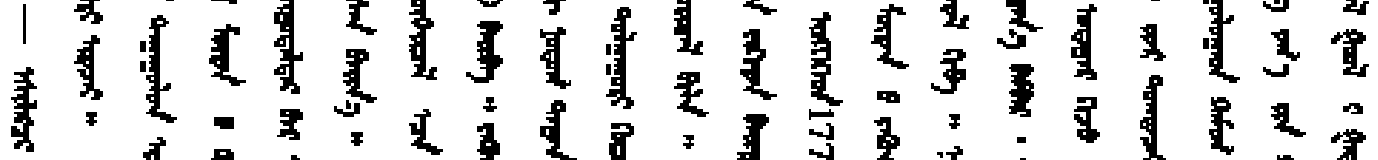

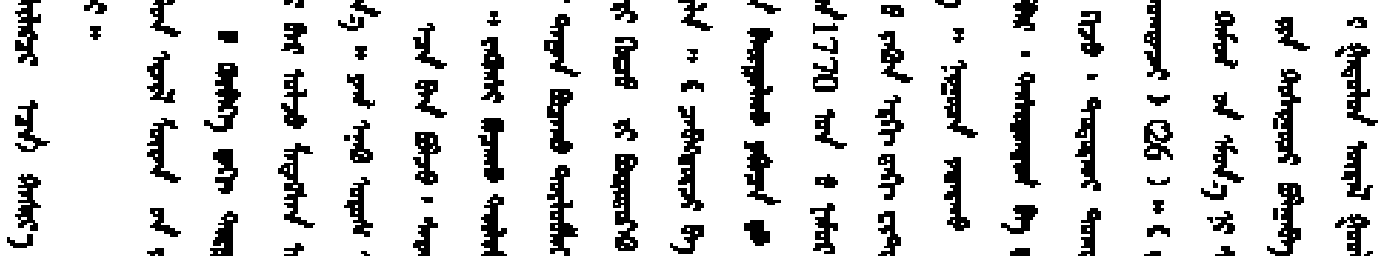
-

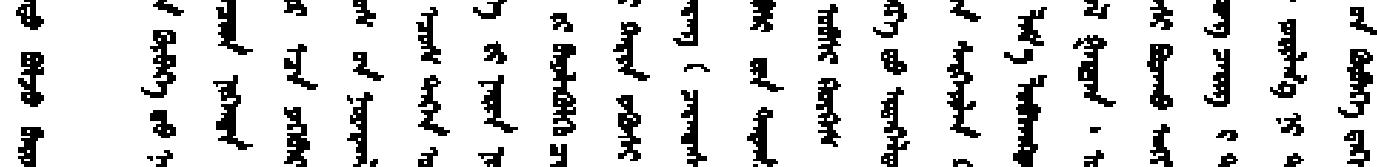

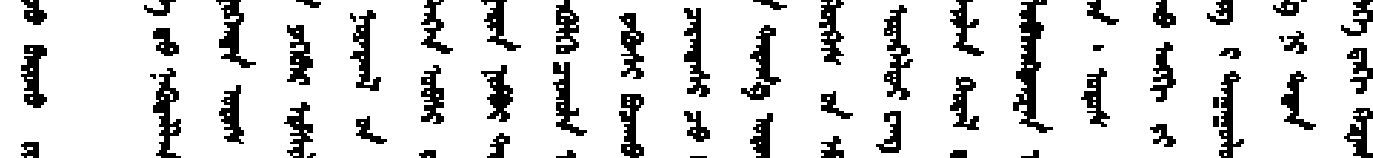

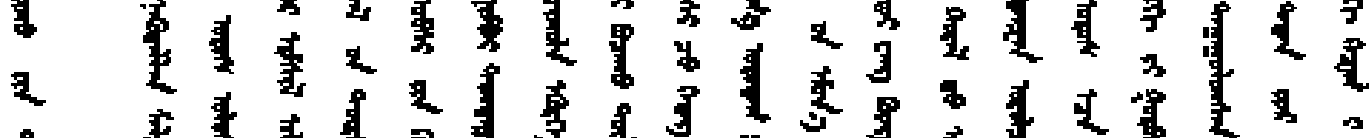

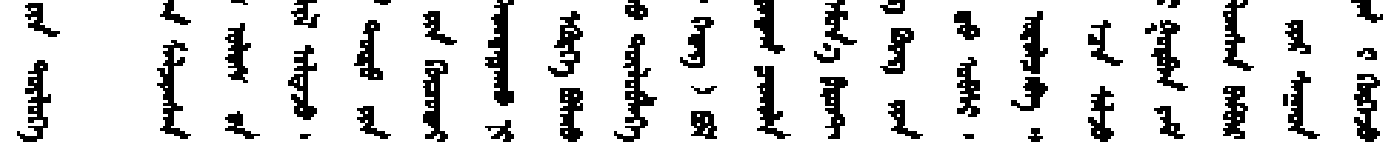




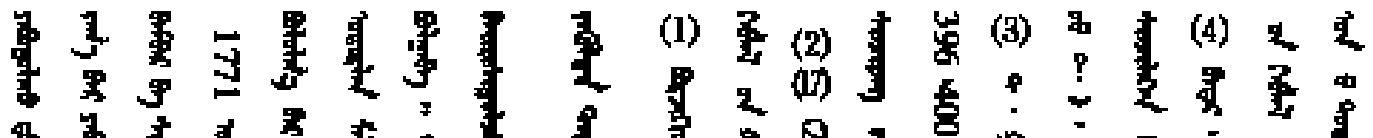

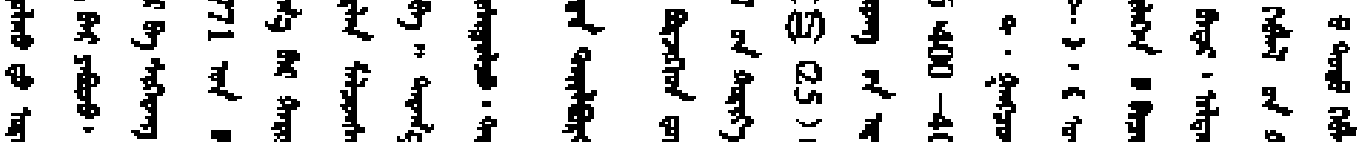

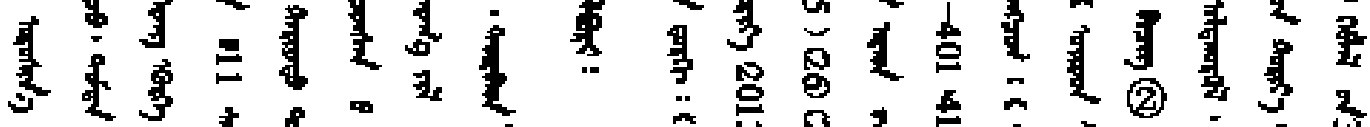

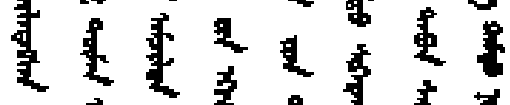

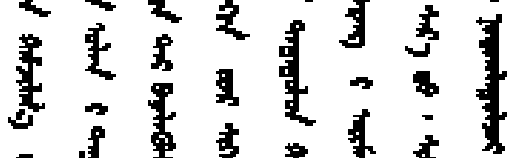

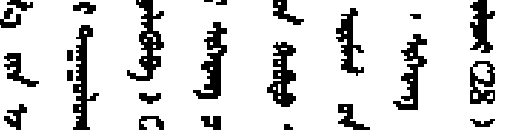

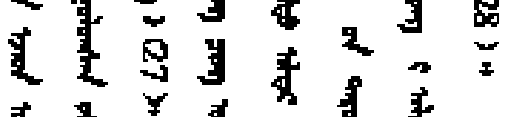

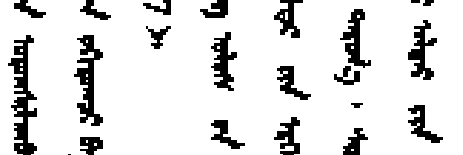

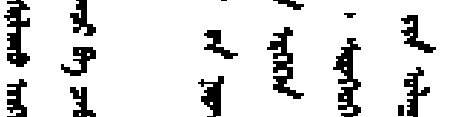

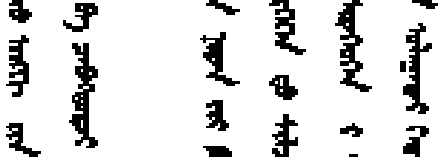

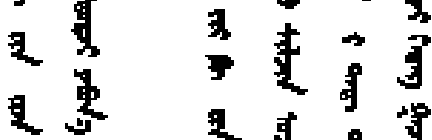

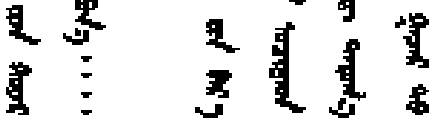

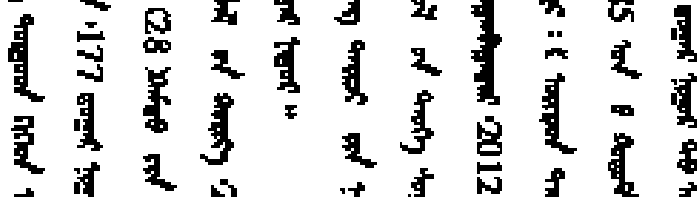

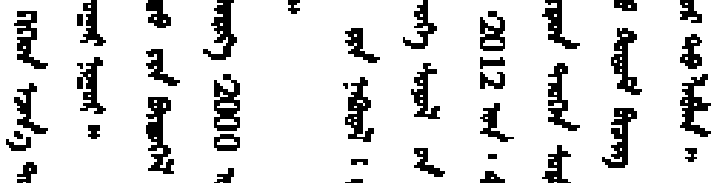

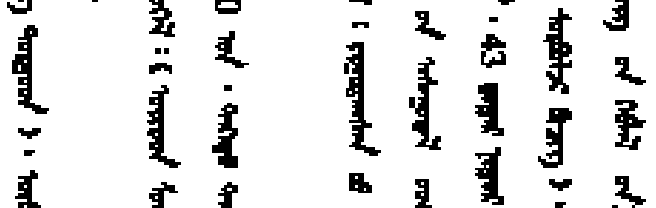

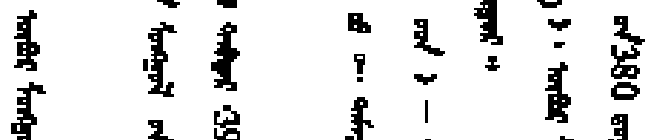

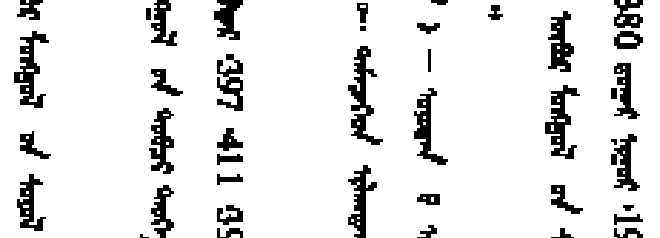

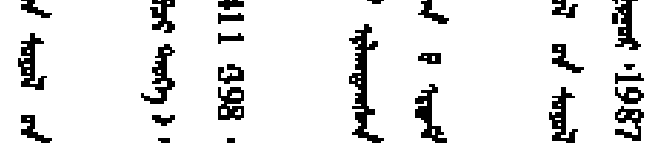

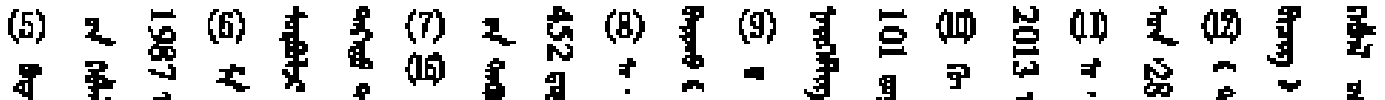

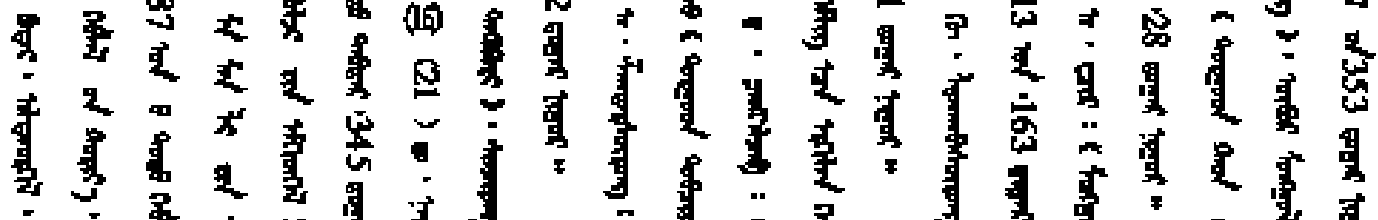

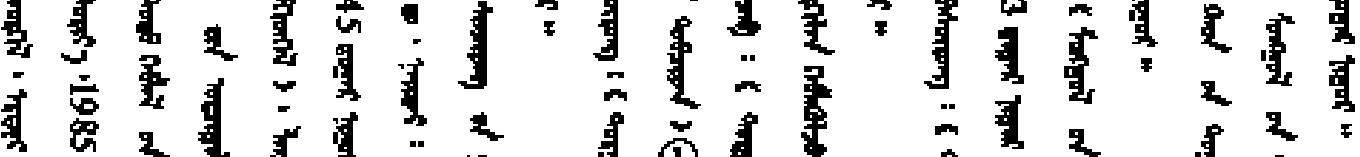

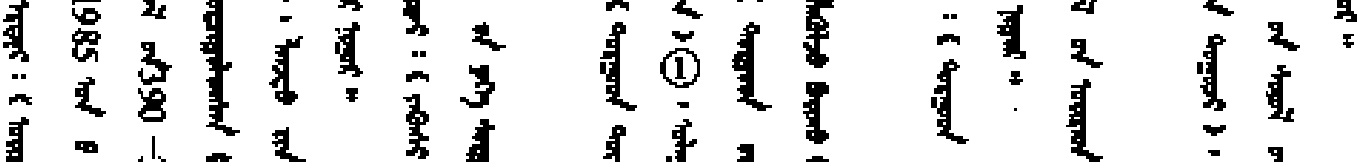

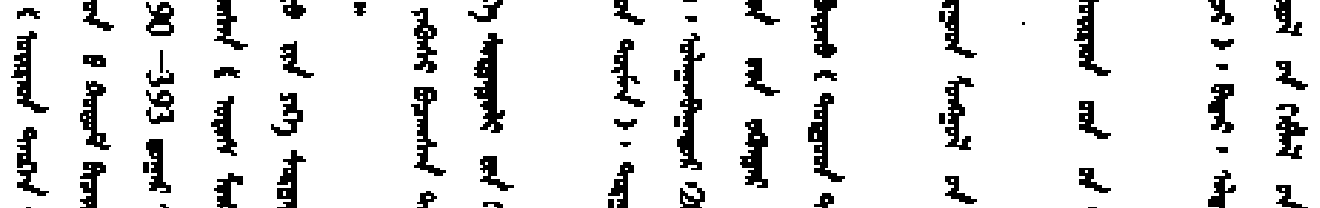

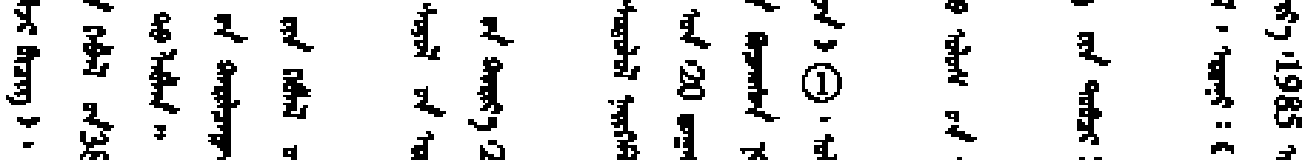

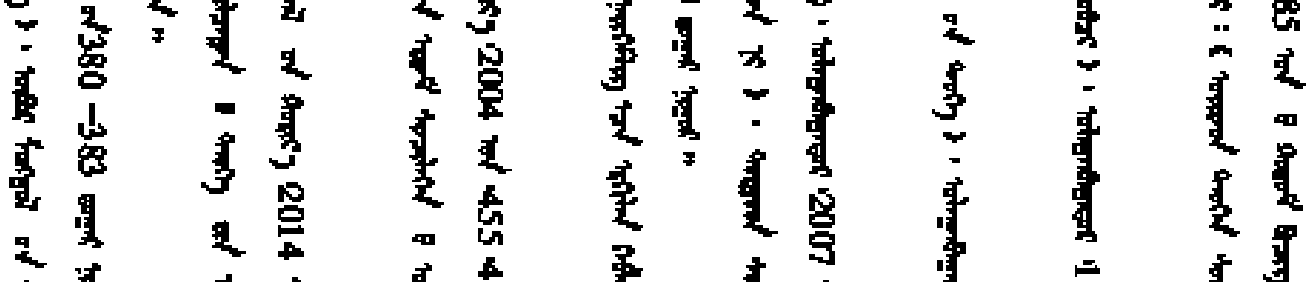

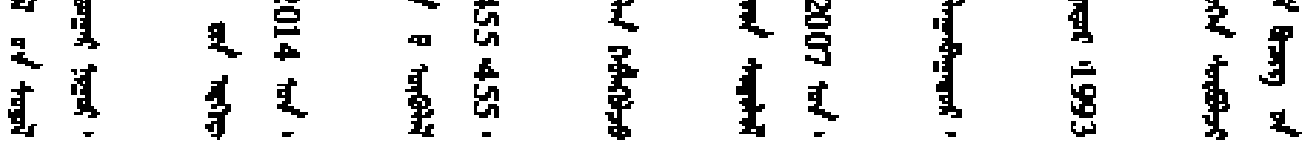




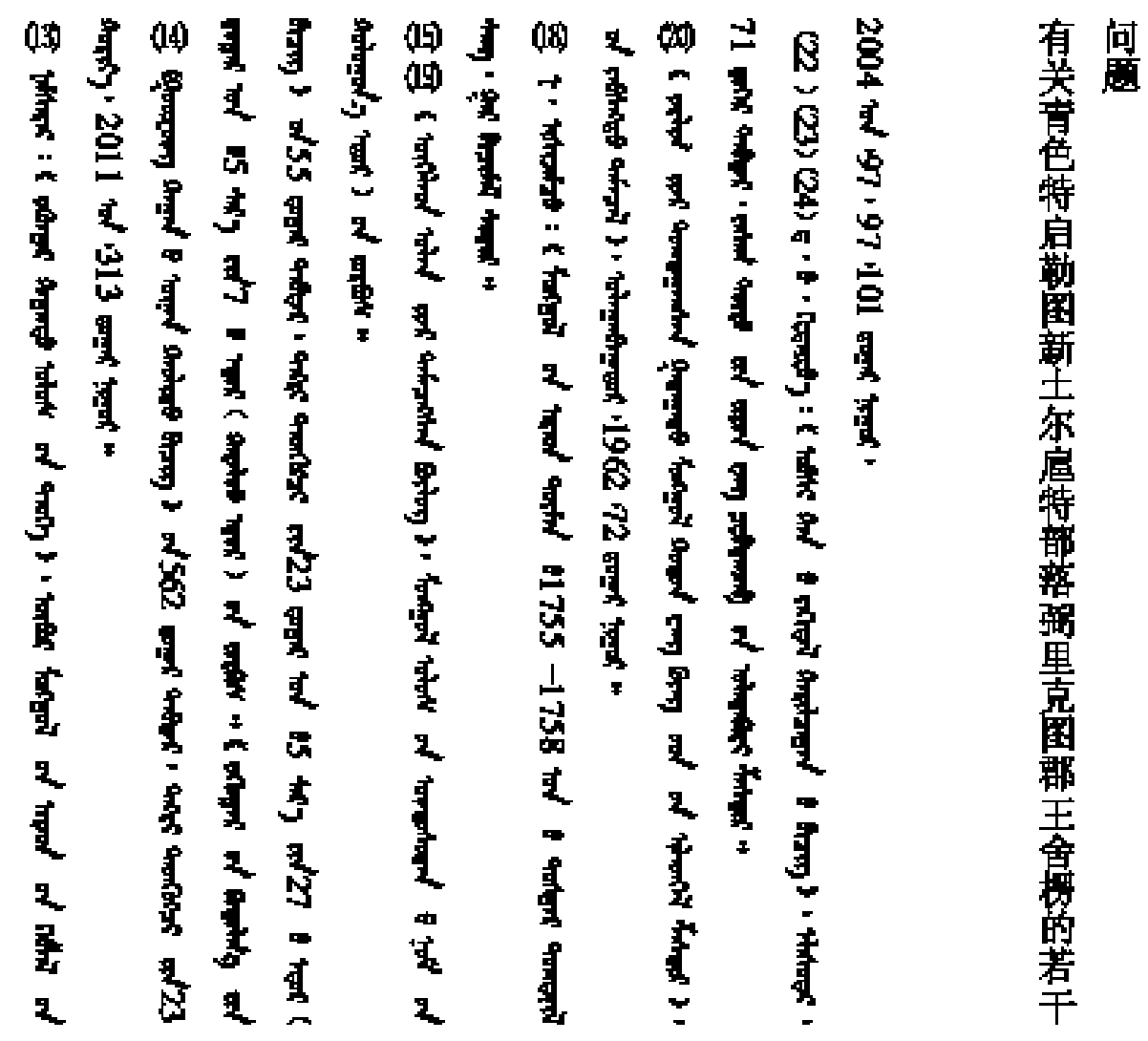

